\title{
Simultaneous application of iron and aluminum anodes for nitrate removal: a comprehensive parametric study
}

\author{
F. Ghanbari - M. Moradi - A. Mohseni-Bandpei • \\ F. Gohari · T. Mirtaleb Abkenar · E. Aghayani
}

Received: 11 November 2013/Revised: 13 February 2014/Accepted: 19 April 2014/Published online: 20 May 2014

(C) Islamic Azad University (IAU) 2014

\begin{abstract}
Exposure to high concentration of nitrate through drinking water poses a threat to human health and environment. Electrocoagulation (EC) is an alternative water treatment process that involves electrogeneration of coagulant agents. In the present study, EC was exerted for the nitrate removal in a batch reactor using aluminum and iron anodes simultaneously. The effects of the main parameters including electrical current, initial $\mathrm{pH}, \mathrm{NaCl}$ dosage, initial nitrate concentration and presence of turbidity on $\mathrm{NO}_{3}{ }^{-}$removal were investigated. $\mathrm{NO}_{2}{ }^{-}$as a byproduct was monitored during electrolysis, and nitratenitrite index was calculated. The results indicated that optimum condition was $\mathrm{pH}$ of 5,300 mA electrical current, $100 \mathrm{mg} / \mathrm{L} \mathrm{NaCl}$ and electrolysis time of $40 \mathrm{~min}$, under which removal efficiency was $81.5 \%$. Nitrite anion was generated during electrolysis of nitrate solution which increases nitrate-nitrite index at the first reaction time, and it was eliminated after 20-min electrolysis time. Reaction kinetic of nitrate removal in the absence and presence of turbidity was first-order and zero-order, respectively.
\end{abstract}

Keywords Electrocoagulation - Nitrite $\cdot$ Turbidity effect · $\mathrm{Al}-\mathrm{Fe}$ anodes

\footnotetext{
F. Ghanbari

Department of Environmental Health Engineering, School of Public Health, Ahvaz Jundishapur University of Medical

Sciences, Ahvaz, Iran

M. Moradi · A. Mohseni-Bandpei $(\bowtie) \cdot$ F. Gohari ·

T. Mirtaleb Abkenar E. Aghayani

Department of Environmental Health Engineering, School of Public Health, Shahid Beheshti University of Medical Sciences (SBMU), Tehran, Iran

e-mail: mohseni.sbmu@gmail.com
}

\section{Introduction}

Groundwater is a critical freshwater resource throughout the world because of its consumption as drinking water. Thus, contamination of groundwater can make it unacceptable for use. Among anionic environmental contaminants, nitrate $\left(\mathrm{NO}_{3}{ }^{-}\right)$is a global problem for pollution of groundwater. Nitrate contamination in water resource comes from agricultural activities, industrial wastewater disposal, infiltration of landfill leachate and animal wastes, particularly from animal farms (Reyter et al. 2008; Shrimali and Singh 2001). Excessive nitrate concentration in drinking water may cause several problems for human health. The most important health concern associated with nitrate is methemoglobinemia that can cause death of infants $<6$ months through its conversion to nitrite. Also, $\mathrm{NO}_{3}{ }^{-}$and $\mathrm{NO}_{2}{ }^{-}$are linked to formation of nitrosamines which are probable carcinogenic compounds affecting the human health in adverse manner (Huang et al. 1998; Samatya et al. 2006; Tada et al. 2004). The recommended maximum limit of $\mathrm{NO}_{3}{ }^{-}$in drinking water is $50 \mathrm{mg} / \mathrm{L}$ in accordance with World Health Organization (WHO) and Institute of Standards and Industrial Research of Iran (ISIRI) (ISIRI 2010; WHO 2011). In addition, nitrate imposes several environmental problems. Nitrates along with phosphates induce eutrophication that is indicated by significant algal growth, as they are both critical nutrients for the phenomenon (Chabani et al. 2006; WHO 2011).

Conventional drinking water treatment processes are not adequate to remove nitrate as compared to other pollutants due to its stability, high solubility and low sorption of nitrate (Kapoor and Viraraghavan 1997; Wang and Wang 2013). Therefore, in recent years, a variety of processes have been developed and implemented for nitrate removal from polluted water. These processes 
include denitrification process (Wang and Wang 2013), chemical reduction (Huang et al. 1998), membrane processes (Ahn et al. 2008), ion exchange and adsorption (Samatya et al. 2006; Xu et al. 2013). These methods suffer from drawbacks. Biological process efficiency is severely dependent on $\mathrm{pH}$ and temperature. Not only adsorption method generates saline wastes which impose disposal problems but also adsorbent regeneration is the main disadvantage of this process. Chemical processes apply a large amount of chemicals that can result in secondary pollution. Membrane and ion exchange processes are considered as alternative techniques for nitrate removal; however, they are not economical because of high operational cost (Can et al. 2006; Kapoor and Viraraghavan 1997; Shrimali and Singh 2001; Xu et al. 2013).

Nowadays, electrochemical treatment for pollutants removal is interesting for environmental scientists and specialists. Among electrochemical processes, electrocoagulation (EC) is a conventional process for removal of different pollutants that utilizes iron and aluminum anodes for in situ generation of coagulant agents in electrochemical reactor (Martínez-Huitle and Brillas 2009). When iron and aluminum are applied as anode, their metal hydroxides are formed in aqueous solution that eliminate soluble and insoluble pollutants based on two mechanisms of precipitation and adsorption (Martínez-Huitle and Brillas 2009; Mollah et al. 2001). Equations 1-3 are the main electrochemical reactions for reactors with $\mathrm{M}$ anodes for the production of coagulants.

Anode: $\mathrm{M} \rightarrow \mathrm{M}^{n+}+n \mathrm{e}^{-}$

Cathode: $n \mathrm{H}_{2} \mathrm{O}+n \mathrm{e}^{-} \rightarrow \frac{n}{2} \mathrm{H}_{2}+n \mathrm{OH}^{-}$

Overall: $\mathrm{M}^{n+}+n \mathrm{H}_{2} \mathrm{O} \rightarrow \mathrm{M}(\mathrm{OH})_{n}$

Recently, EC has been used in removing nitrate (Lakshmi et al. 2013) and other pollutants such as lead (Kamaraj et al. 2013) as well as treatment of wastewaters (Ozyonar and Karagozoglu 2012; Sridhar et al. 2013). Many studies were carried out the removal of nitrate by EC process using iron and aluminum anodes separately (Lacasa et al. 2011; Lakshmi et al. 2013). Meanwhile, in the present study, iron and aluminum anodes are exerted both together in an electrochemical cell in monopolar arrangement for generation of both coagulants simultaneously. Also, effects of various parameters of EC process on removal of nitrate were investigated. Among these parameters, the presence of turbidity was studied as a critical factor in nitrate removal rate which has not been considered. Finally, $\mathrm{NO}_{2}$ as a by-product was monitored during electrolysis time and nitrate-nitrite index was calculated for assessment of drinking water quality based on WHO guideline. This study was carried out in Shahid
Beheshti University of Medical Sciences (SBMU), Tehran, Iran, in Spring 2013.

\section{Materials and methods}

\section{Materials}

Sodium nitrate, sodium chloride, hydrochloric acid and sodium hydroxide were obtained from Merck Company. All solutions were prepared with deionized water. A nitrate stock solution was made from sodium nitrate $\left(\mathrm{NaNO}_{3}\right)$ daily. Kaolinite and milk powder were provided commercially for preparation of mineral and organic turbidity, respectively.

\section{Experimental setup}

The experimental setup used in this study is shown in Fig. 1. Electrochemical cell consists of a glass vessel of $800 \mathrm{~mL}$ containing $600 \mathrm{~mL}$ electrolyte. In the EC, the cathode electrodes are not prone to corrosion, so one pair of copper plates was selected. Iron and aluminum were used as anodes for electrogeneration of coagulant agents simultaneously. All electrode dimensions were $3 \times 0.1 \times$ $12 \mathrm{~cm}$. The active area of electrodes immersed in the solution was $84 \mathrm{~cm}^{2}$ that provides a $S / V$ ratio of $14 \mathrm{~m}^{2} / \mathrm{m}^{3}$. The gap between anodes and cathodes was maintained at $20 \mathrm{~mm}$. A digital DC power supply (Zhaoxin, China) with an electrical current range of $0-2 \mathrm{~A}$ and a voltage range of $0-20 \mathrm{~V}$ was used for the experiments.

In each experiment, $600 \mathrm{~mL}$ of nitrate solution was poured into electrochemical cell. Prior to the beginning of

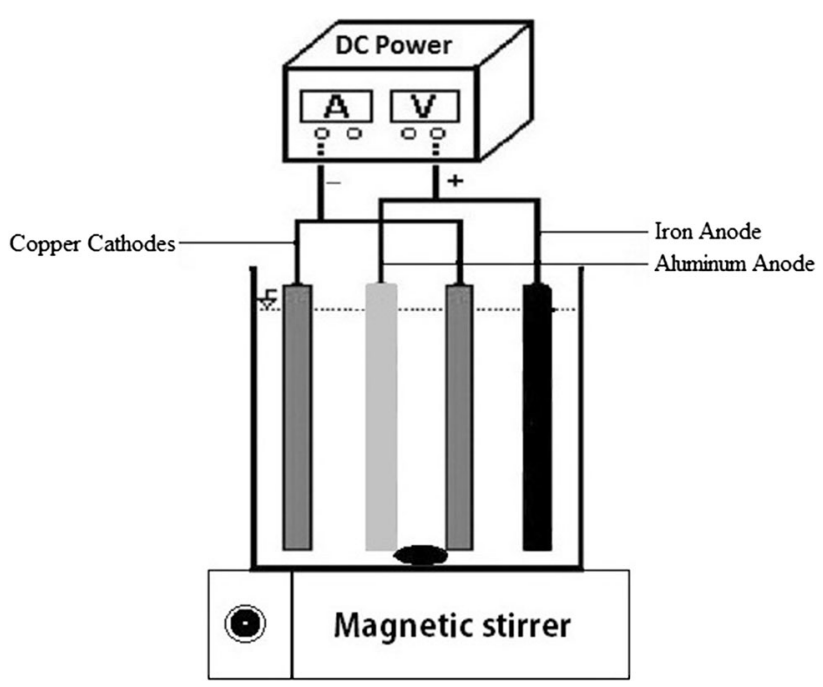

Fig. 1 Schematic setup of electrocoagulation reactor in this study 
the electrolysis, the $\mathrm{pH}$ of the solution was adjusted using $0.1 \mathrm{~N} \mathrm{HCl}$ or $0.1 \mathrm{~N} \mathrm{NaOH}$, while in order to increase conductivity, $\mathrm{NaCl}$ was added. A magnetic stirrer was used to provide adequate mixing in the electrochemical cell. Samples were taken during each run at different times and were filtered through Whatman filter paper (No. 42) before the analysis of nitrate concentration. All the experiments were repeated twice, and the results are the average of at least two measurements with a variation of $\pm 5 \%$. The effects of initial solution $\mathrm{pH}$, electrical current, reaction time, $\mathrm{NaCl}$ concentration, initial nitrate concentration and the presence of turbidity were investigated. Electrical energy consumption was calculated. Likewise, nitrite concentration was monitored as a by-product.

\section{Analytical methods}

Nitrate and nitrite samples were measured by a UV-Vis spectrophotometer (DR5000, Hach). The nitrate concentration was measured based on method of ultraviolet absorbance at $220 \mathrm{~nm}$ wavelength which was corrected by subtracting absorbance at $275 \mathrm{~nm}$ wavelength multiplied by two based on Eq. 4 (APHA 1999):

Nitrate absorbance: UV absorbance at $220 \mathrm{~nm}-2$

$\times(\mathrm{UV}$ absorbance at $275 \mathrm{~nm})$

The nitrite concentration was determined by colorimetric method using Hach test kits. Turbidity of water was analyzed by a Hach $2100 \mathrm{~N}$ turbidimeter. The $\mathrm{pH}$ meter (Corning 120) was used to measure the $\mathrm{pH}$ value of solution in each experiment.

\section{Results and discussion}

\section{Effect of anode materials}

Since coagulant agents are introduced to the solution through the electrical dissolution of anode, anode material is undoubtedly a crucial factor in EC process (Yavuz et al. 2011). So far, iron and aluminum have been the most commonplace anode materials within EC processes, representing various results, endorsing that each of these two materials might be superior to the other one depending on the experimental conditions. In this way, three conditions were investigated and the results are demonstrated in Fig. 2. As shown, nitrate removal had its highest and lowest efficiencies in $\mathrm{Al}-\mathrm{Fe}$ and $\mathrm{Al}-\mathrm{Al}$ configurations, respectively. In separate application of iron and aluminum as anode, it was observed that iron provided higher efficiency. It is assumed to be due to higher adsorption capacity of hydrous ferric oxides in comparison with that of the hydrous aluminum oxides (Modirshahla et al. 2008).

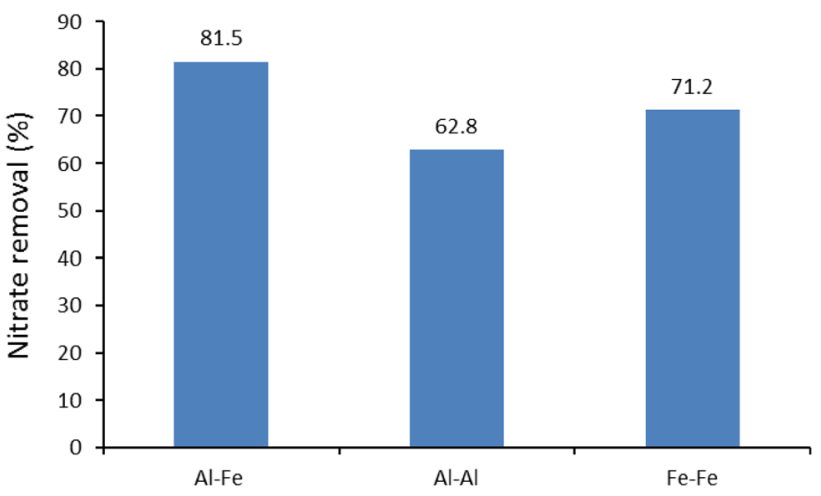

Fig. 2 Effect of anode material on nitrate removal (applied current $=300 \mathrm{~mA}, 100 \mathrm{mg} / \mathrm{L} \mathrm{NO}_{3}{ }^{-}, 100 \mathrm{mg} / \mathrm{L} \mathrm{NaCl}, \mathrm{pH} 5$ and $40-\mathrm{min}$ reaction time)

In simultaneous application of iron and aluminum as anode materials, the highest nitrate removal efficiency was provided. It is also hypothesized to be attributed to the synergist effect brought about by simultaneous application of $\mathrm{Fe}$ and $\mathrm{Al}$ as anode. Hence, subsequent experiments were conducted in condition of $\mathrm{Al}-\mathrm{Fe}$ configuration.

\section{Effects of $\mathrm{pH}$ and electrical current}

The $\mathrm{pH}$ of the solution plays a crucial role in the performance of the EC process (Thakur et al. 2009). The solubility of released coagulants from sacrificial anodes is affected by several factors, one of which is the $\mathrm{pH}$ of the solution. In this study, the dependency of removal efficiency on initial $\mathrm{pH}$ values was studied in the $\mathrm{pH}$ range of 3-9. The nitrate removal efficiency, as a function of $\mathrm{pH}$, is shown in Fig. 3 for the initial nitrate concentration of $100 \mathrm{mg} / \mathrm{L}$, electrical current of $200 \mathrm{~mA}$ and 40 -min reaction time. It is clearly seen from Fig. 3 that optimum nitrate removal was achieved at $\mathrm{pH} 5$, since there is a rapid drop in the nitrate concentration from 100 to $28.4 \mathrm{mg} / \mathrm{L}$ in $40 \mathrm{~min}$

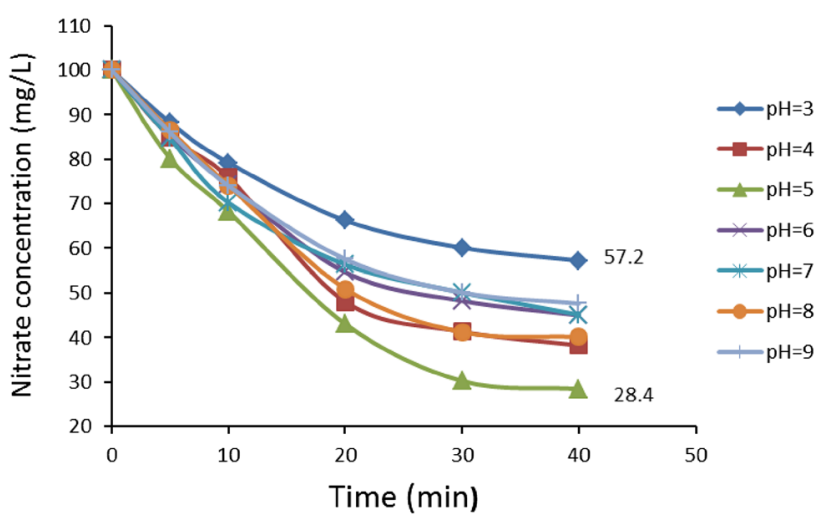

Fig. 3 Effect of $\mathrm{pH}$ on nitrate removal (applied current $=200 \mathrm{~mA}$ and $100 \mathrm{mg} / \mathrm{L} \mathrm{NaCl}$ ) 
of reaction time which is equivalent to an efficiency of $71.6 \%$. Expectedly, minimum removal efficiency occurred at $\mathrm{pH} 3$. This is related to the dominant aluminum and iron species that are more soluble at $\mathrm{pH}$ of 3 than at other $\mathrm{pH}$ values. It is obvious that these soluble species are not useful for water treatment in case of coagulating agents since they do not provide an effective adsorbing surface (Martínez-Huitle and Brillas 2009; Yavuz et al. 2011). In addition, at alkaline $\mathrm{pH}$, the oxide surface has a net negative charge and would tend to repulse the anionic nitrate in solution (Vasudevan et al. 2010). Hence, $\mathrm{pH}$ is supposed to act as a bilateral factor since either high or low $\mathrm{pH}$ values do not provide enough efficiency.

Electrical current is the paramount parameter affecting the removal efficiency and controlling the reaction rate in the EC process (Thakur et al. 2009; Vasudevan et al. 2010). It is evident that in the EC process, the coagulant dosage together with the bubble production rate and size of the flocs is specified by the electrical current, simultaneously (Yavuz et al. 2011). To determine the effect of electrical current on the nitrate removal, a series of experiments were carried out on solutions containing constant nitrate concentration of $100 \mathrm{mg} / \mathrm{L}$ with the electrical current varying from 100 to $400 \mathrm{~mA}$. Figure 4 illustrates the nitrate removal efficiency versus the reaction time for different electrical current values. As shown in Fig. 4, the increasing trend of electrical current results in greater percentage increase in nitrate removal efficiency. It is assumed that higher electrodissolution causes removal of protective oxide layers from the surface of the electrodes (Lacasa et al. 2011). The highest electrical current (400 mA) provided the most favorable treatment with $>80 \%$ nitrate removal; however, the electrical current of $300 \mathrm{~mA}$ approximately satisfied the former removal efficiency with a slight difference which is economically negligible,

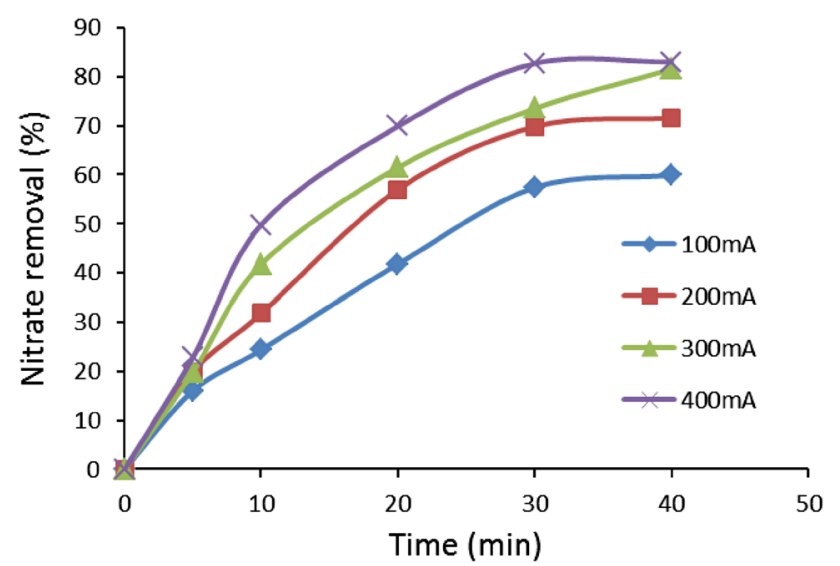

Fig. 4 Effect of electrical current on nitrate removal (pH 5, $100 \mathrm{mg} / \mathrm{L}$ $\mathrm{NaCl}$ and $100 \mathrm{mg} / \mathrm{L} \mathrm{NO}_{3}{ }^{-}$) consuming less energy along with producing less sludge. This is attributed to the fact that the amount of produced $\mathrm{Al}^{3+}$ and $\mathrm{Fe}^{2+}$ depends on electrical current. According to the Faraday's law, as the electrical current increases, the corrosion rate at the anode increases (Martínez-Huitle and Brillas 2009; Thakur et al. 2009). With the increase in anode corrosion, the amount of produced metal hydroxides augments, so the removal efficiency rises (Malakootian et al. 2011).

Effects of $\mathrm{NaCl}$ and initial nitrate concentration

The influence of electrolyte dosage on the removal of nitrate was investigated. $\mathrm{NaCl}$ was chosen as the supporting electrolyte because it does not interfere in the electrochemical reactions. In this way, $\mathrm{NaCl}$ was applied to provide adequate electrical conductivity, thereby decreasing the electrical energy consumption (Zhang et al. 2013). To evaluate the effect of $\mathrm{NaCl}$, the electrical current and $\mathrm{pH}$ were held constant at $300 \mathrm{~mA}$ and 5, respectively, during 40-min reaction time. The variation in nitrate concentration versus time in different $\mathrm{NaCl}$ concentrations is shown in Fig. 5. As is shown in Fig. 5, nitrate removal in the presence of sodium chloride is remarkably higher in comparison with the condition that no supporting electrolyte was employed. The presence of chloride ion reduces the passivation layer on anode electrodes, leading to increase in anodic dissolution of iron and aluminum (Zhang et al. 2013). In addition, available metal coagulants in solution increase by increasing $\mathrm{NaCl}$ dosage that is referred to the reduction in oxide layer (Golder et al. 2007). Nevertheless, further increase in $\mathrm{NaCl}$ from 100 to $500 \mathrm{mg} / \mathrm{L}$ does not provide significantly less nitrate concentration. Therefore, the optimum concentration of $\mathrm{NaCl}$ recommended is $100 \mathrm{mg} / \mathrm{L}$.

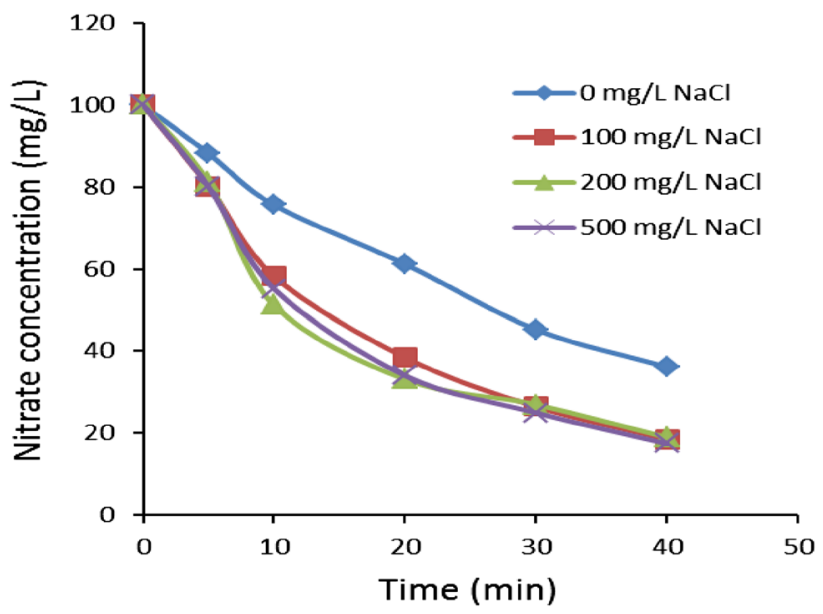

Fig. $5 \mathrm{NaCl}$ dosage effect on nitrate removal (pH 5 and applied current $=300 \mathrm{~mA}$ ) 


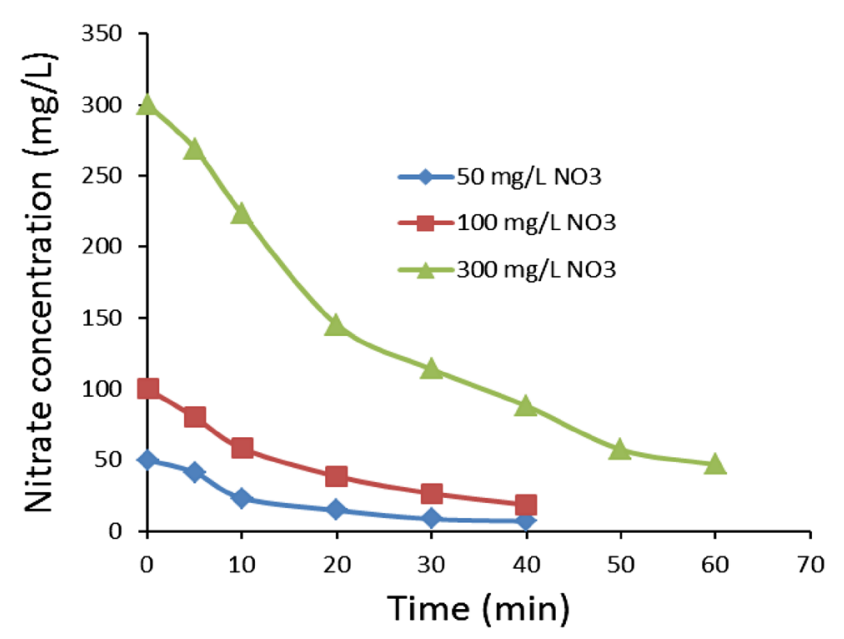

Fig. 6 Effect of initial nitrate concentration on nitrate removal ( $\mathrm{pH} 5$, $100 \mathrm{mg} / \mathrm{L} \mathrm{NaCl}$ and applied current $=300 \mathrm{~mA}$ )

The effect of initial nitrate concentrations of 50,100 and $300 \mathrm{mg} / \mathrm{L}$ was investigated at electrical current of $300 \mathrm{~mA}, \mathrm{pH}$ 5 and $100 \mathrm{mg} / \mathrm{L} \mathrm{NaCl}$ in each experiment, and the results are illustrated in Fig. 6. It can be seen that as initial nitrate concentration increased, nitrate concentration decreased since adsorption capacity of flocs is limited, so the flocs are able to adsorb specific amount of nitrate (Chang et al. 2007; Modirshahla et al. 2008). Besides, with an increase in nitrate concentration, the amounts of iron and aluminum hydroxide complexes produced are inadequate to coagulate the excessive concentration of pollutant. Within mentioned experimental condition, nitrate concentration was mostly decreased in the lowest selected initial concentration. Furthermore, it is worthwhile to consider that nitrate concentration undergoes similar descending trends in 50 and $100 \mathrm{mg} / \mathrm{L}$ initial nitrate concentration. In terms of removal efficiency, during 40-min electrolysis time, removal efficiencies were 86.2, 81.5 and $70.6 \%$ for initial concentrations of 50, 100 and $300 \mathrm{mg} / \mathrm{L}$, respectively. Noticeably, in the highest initial concentration $(300 \mathrm{mg} /$ $\mathrm{L}$ ), reaction time was extended to $60 \mathrm{~min}$ to fulfill the WHO guideline of $50 \mathrm{mg} / \mathrm{L}$ for nitrate as $\mathrm{NO}_{3}{ }^{-}$. While in a study conducted by Koparal and Öğ̈̈tveren (2002) with iron electrodes and $300 \mathrm{mg} / \mathrm{L}$ initial nitrate concentration, it took more than 60-min electrolysis time to achieve similar result. In comparison with the study of Emamjomeh and Sivakumar (2009) in which Al electrodes were used, nitrate concentration in our study was decreased to $<50 \mathrm{mg} / \mathrm{L} \mathrm{NO}_{3}{ }^{-}$in less time and electrical current when initial concentration was $300 \mathrm{mg} / \mathrm{L}$ $\mathrm{NO}_{3}{ }^{-}$. Eventually, it can be stated that by increasing the initial nitrate concentration, the required time to gain the desired amount of nitrate increases (Emamjomeh and Sivakumar 2009).

Effect of turbidity on nitrate removal

Turbidity is a physical parameter affecting efficiency of the water treatment processes. In order to assess the turbidity effect, synthetic turbid water was prepared by kaolinite and milk powder for inorganic and organic turbidity of water, respectively. Figure 7a shows nitrate reduction in the presence of $50 \mathrm{NTU}$ organic or inorganic turbidity at electrical current of $300 \mathrm{~mA}, \mathrm{pH}$ of 5 and $100 \mathrm{mg} / \mathrm{L} \mathrm{NaCl}$. It can be seen that the presence of the turbidity in both forms has inhibitory effect on nitrate removal. In fact, the turbidity competes with nitrate for collision with surface sites of flocs (Ge and Zhu 2008). The presence of colloidal particles with
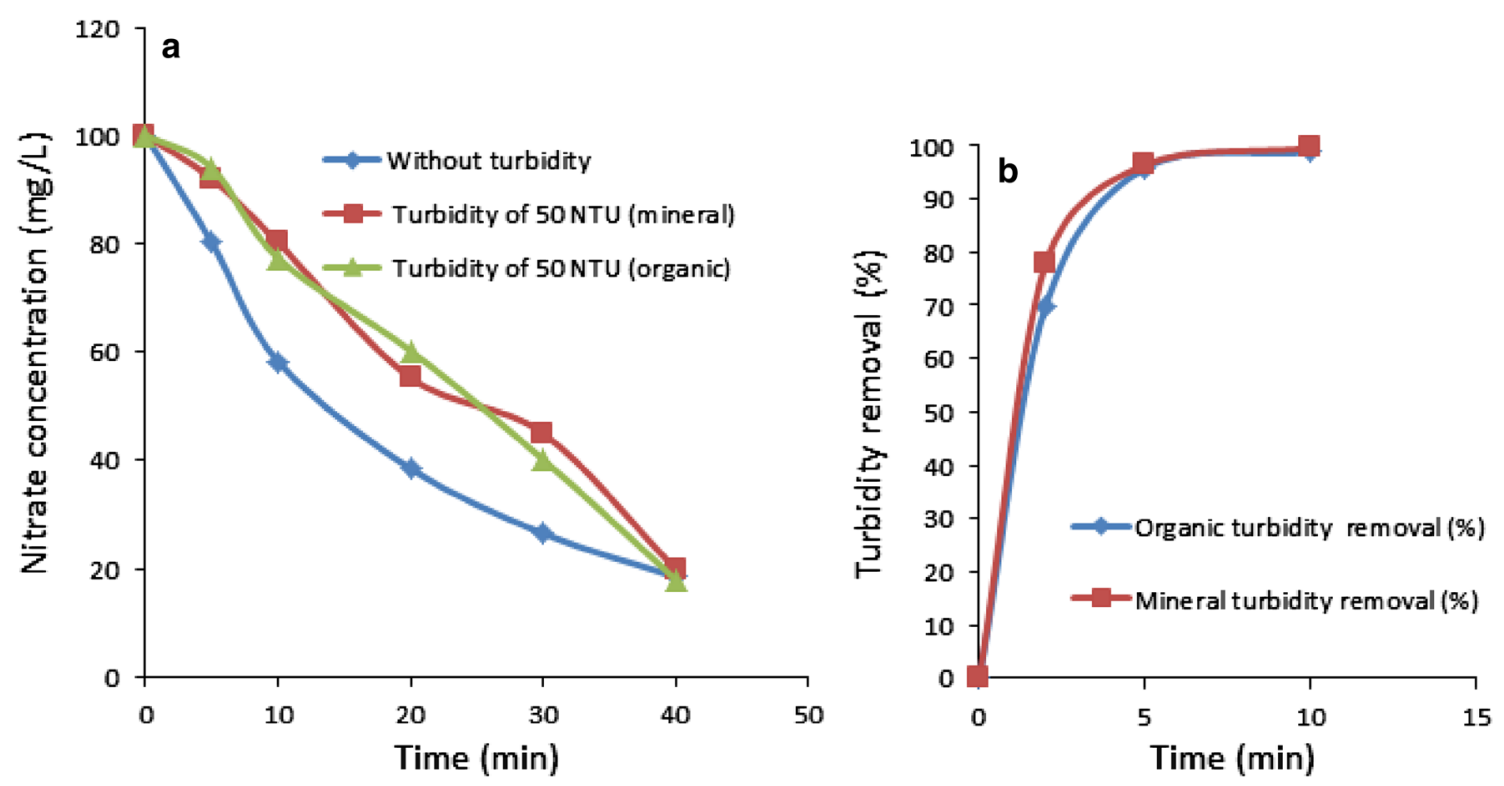

Fig. 7 a Effect of turbidity on nitrate removal and b turbidity removal efficiency $(\mathrm{pH} 5,100 \mathrm{mg} / \mathrm{L} \mathrm{NaCl}$ and applied current $=300 \mathrm{~mA}$ ) 
Table 1 Kinetic constant of nitrate removal in different conditions

\begin{tabular}{|c|c|c|c|c|c|}
\hline Various statuses & $R_{\text {Zero-order }}^{2}$ & $R_{\text {First-order }}^{2}$ & $R_{\text {Second-order }}^{2}$ & Rate constant & $\mathrm{t}_{(1 / 2)}(\min )$ \\
\hline Nitrate (in the absence of turbidity) & 0.912 & 0.992 & 0.977 & $0.0422 \mathrm{~min}^{-1}$ & 16.42 \\
\hline Nitrate (in the presence of mineral turbidity) & 0.995 & 0.939 & 0.795 & $2.06 \mathrm{mg} / \mathrm{min}$ & 24.27 \\
\hline Nitrate (in the presence of organic turbidity) & 0.989 & 0.938 & 0.798 & $1.98 \mathrm{mg} / \mathrm{min}$ & 25.25 \\
\hline
\end{tabular}
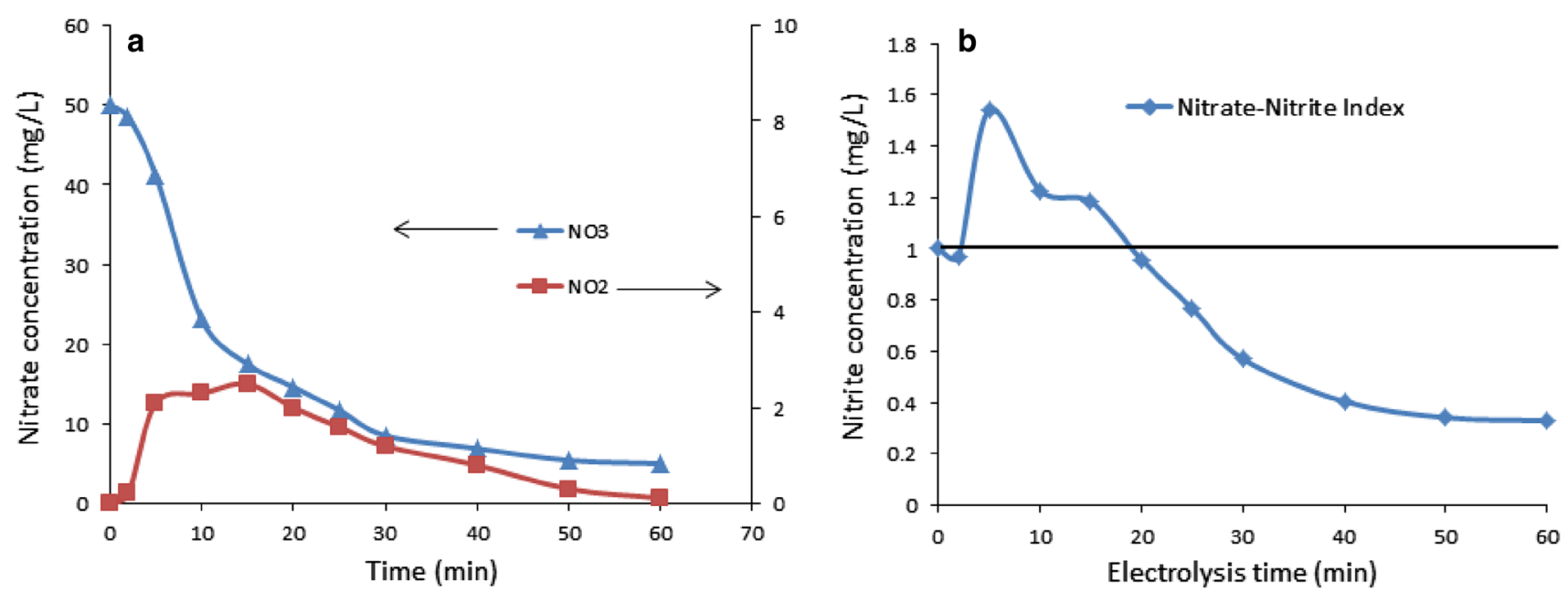

Fig. 8 a $\mathrm{NO}_{2}$ monitoring as a by-product and $\mathbf{b}$ nitrate-nitrite index $(\mathrm{pH} 5,100 \mathrm{mg} / \mathrm{L} \mathrm{NaCl}$ and applied current $=300 \mathrm{~mA})$

negative charge creates a competitive condition in which nitrate agglomeration is affected in an adverse manner. Furthermore, the high efficiency of turbidity removal within both forms in Fig. 7b illustrated that turbidity can disturb the adsorption of nitrate on electrogenerated coagulants, thereby decreasing the rate of nitrate removal. Moreover, results obtained from Fig. 7a, b show that type of turbidity has no influence on nitrate and turbidity removal efficiencies. In addition, it is revealed that this electrochemical process can coagulate soluble and colloidal agents concurrently.

The results of Fig. 7a were evaluated by zero-order, firstorder and second-order kinetic models for investigation of the rate constant. The values of $k_{1}$ and $R^{2}$ for $100 \mathrm{mg} / \mathrm{L} \mathrm{NO}_{3}{ }^{-}$in three conditions were determined from the linear plots (plots are not given) and are summarized in Table 1. In case of nitrate removal (in the absence of turbidity), according to $R^{2}$ values, first-order kinetic was suitable with $R^{2}=0.992$ and $k_{1}=0.0422 \mathrm{~min}^{-1}$, which is in agreement with the result of kinetic study carried out by Emamjomeh and Sivakumar (2009). An interesting result is observed in kinetic models when turbidity has been added to nitrate solution. In this way, the rate of reaction decreased in the presence of turbidity and kinetic model shifted from first-order to zero-order with $k_{1}=2.06$ and $1.98 \mathrm{mg} / \mathrm{min}$ for mineral and organic turbidity, respectively. This result is due to inhibition effect of turbidity on nitrate removal as described above. In addition, the half-life value was calculated for nitrate removal in three statuses. It is obvious that the half-life value of nitrate increased greatly from $16.42 \mathrm{~min}$ in the absence of turbidity to 24.27 and $25.25 \mathrm{~min}$ in the presence of turbidity. For the nitrate removal (in the absence of turbidity), half-life is independent of initial nitrate concentration since it follows first-order reaction, while this value in the presence of turbidity depends on initial nitrate concentration highly (Chang 2010).

$\mathrm{NO}_{2}$ monitoring as a by-product

Nitrite is a hazardous pollutant that can harm human health and the environment. During electrolysis of nitrate solution, nitrite may be produced by the reduction of nitrate based on Eqs. 5 and 6 (Koparal and Öğütveren 2002; Mook et al. 2013).

$\mathrm{NO}_{3}^{-}+\mathrm{H}_{2} \mathrm{O}+2 \mathrm{e}^{-} \rightarrow \mathrm{NO}_{2}^{-}+2 \mathrm{OH}^{-}$

$\mathrm{NO}_{3}^{-}+\mathrm{H}_{2} \rightarrow \mathrm{NO}_{2}^{-}+\mathrm{H}_{2} \mathrm{O}$

As a by-product, it is produced in conditions that nitrate undergoes reduction. In EC, reduction occurs at the cathode. In such condition, nitrate is reduced to nitrite. Hence, as the EC process proceeds, nitrate concentration decreases as nitrite concentration increases slightly. Figure 8a demonstrates the variations in nitrate and nitrite concentrations during 60-min 
Fig. 9 Effect of electrical current on electrical energy consumption (pH 5, $100 \mathrm{mg} / \mathrm{L}$ $\mathrm{NaCl}$ and $100 \mathrm{mg} / \mathrm{L} \mathrm{NO}_{3}{ }^{-}$)

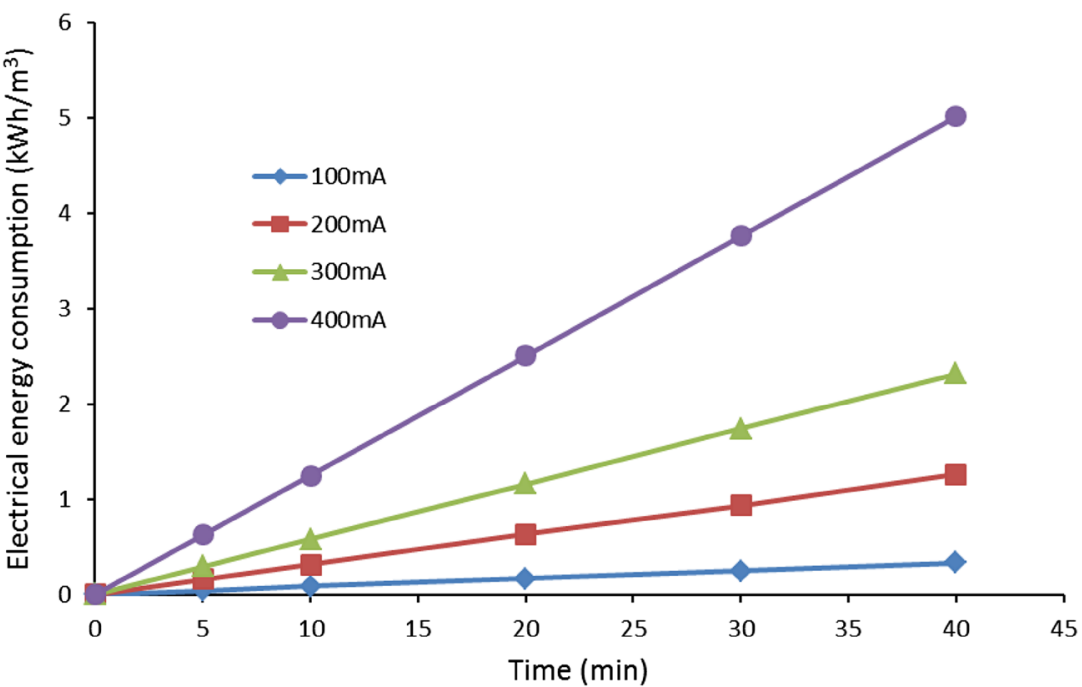

as the most important parameter of economical assessment. The EEC of various electrical currents is shown in Fig. 9.

$\mathrm{EEC}=\frac{U \times i \times t}{v}$

where $U$ is the cell voltage (volt), $i$ is the electrical current (A), $t$ is the electrolysis time (h) and $v$ is the volume of solution in the reactor $\left(\mathrm{m}^{3}\right)$. Regarding Eq. 8, increasing of the electrical current and electrolysis time increases energy consumption. Electrical energy consumption at electrical current of $300 \mathrm{~mA}$ and 40-min electrolysis time was $2.32 \mathrm{kWh} / \mathrm{m}^{3}$. However, increasing the electrical current from 300 to $400 \mathrm{~mA}$ resulted in more than 2 times higher energy consumption which was $5.02 \mathrm{kWh} / \mathrm{m}^{3}$. Various voltages for different electrical currents reveal that electrical current and EEC have not a linear relationship.

\section{Conclusion}

The present study displays that EC with simultaneous application of iron and aluminum anodes can be utilized as an effective process for nitrate removal. The results showed that nitrate removal efficiency was $81.5 \%$ at the $\mathrm{pH}$ of 5 , $300 \mathrm{~mA}$ electrical current, $100 \mathrm{mg} / \mathrm{L} \mathrm{NaCl}$ and $40-\mathrm{min}$ electrolysis time. In addition, this work demonstrates that the presence of turbidity in the solution has an inhibitory effect on nitrate removal. In this way, in the presence of turbidity, reaction kinetic shifted from first-order to zeroorder. Small amount of $\mathrm{NO}_{2}$ anion was generated during electrolysis, and then, it was removed in 60-min reaction time. During the first 15-min reaction time, nitrate-nitrite index was more than 1 , while it reduced to less than 1 after $20 \mathrm{~min}$, finally reaching to the lowest value of 0.3 at 60 min. Electrical energy consumption in optimal condition was $2.32 \mathrm{kWh} / \mathrm{m}^{3}$.
2009). Besides high efficiency, economical aspect is also an important factor that is explored by energy consumption 
Acknowledgments The authors would like to thank Dr. Bagher Fozunbal for cooperating in editing the article.

\section{References}

Ahn J-H, Choo K-H, Park H-S (2008) Reverse osmosis membrane treatment of acidic etchant wastewater: effect of neutralization and polyelectrolyte coating on nitrate removal. J Membr Sci 310(1-2):296-302

APHA (1999) Standard methods for the examination of water and wastewater, 20th edn. APHA, Washington, DC

Can OT, Kobya M, Demirbas E, Bayramoglu M (2006) Treatment of the textile wastewater by combined electrocoagulation. Chemosphere 62(2):181-187

Chabani M, Amrane A, Bensmaili A (2006) Kinetic modelling of the adsorption of nitrates by ion exchange resin. Chem Eng $\mathrm{J}$ 125(2):111-117

Chang R (2010) Chemistry, 10th edn. McGraw-Hill, New York

Chang EE, Hsing H-J, Ko C-S, Chiang P-C (2007) Decolorization, mineralization, and toxicity reduction of acid orange 6 by ironsacrificed plates in the electrocoagulation process. J Chem Technol Biotechnol 82(5):488-495

Emamjomeh MM, Sivakumar M (2009) Denitrification using a monopolar electrocoagulation/flotation (ECF) process. J Environ Manag 91(2):516-522

Ge F, Zhu L (2008) Effects of coexisting anions on removal of bromide in drinking water by coagulation. J Hazard Mater 151(2-3):676-681

Golder AK, Samanta AN, Ray S (2007) Removal of Cr3+ by electrocoagulation with multiple electrodes: bipolar and monopolar configurations. J Hazard Mater 141(3):653-661

Huang C-P, Wang H-W, Chiu P-C (1998) Nitrate reduction by metallic iron. Water Res 32(8):2257-2264

ISIRI (2010) Drinking water-physical and chemical specifications, 1053, 5th edn. Institute of Standards and Industrial Research of Iran, Tehran

Kamaraj R, Ganesan P, Vasudevan S (2013) Removal of lead from aqueous solutions by electrocoagulation: isotherm, kinetics and thermodynamic studies. Int J Environ Sci Technol. doi:10.1007/ s13762-013-0457-z

Kapoor A, Viraraghavan T (1997) Nitrate removal from drinking water: review. J Environ Eng 123(4):371-380

Koparal AS, Ögütveren ÜB (2002) Removal of nitrate from water by electroreduction and electrocoagulation. J Hazard Mater 89(1): 83-94

Lacasa E, Cañizares P, Sáez C, Fernández FJ, Rodrigo MA (2011) Removal of nitrates from groundwater by electrocoagulation. Chem Eng J 171(3):1012-1017

Lakshmi J, Sozhan G, Vasudevan S (2013) Recovery of hydrogen and removal of nitrate from water by electrocoagulation process. Environ Sci Pollut Res 20(4):2184-2192

Malakootian M, Yousefi N, Fatehizadeh A (2011) Survey efficiency of electrocoagulation on nitrate removal from aqueous solution. Int J Environ Sci Technol 8(1):107-114

Martínez-Huitle CA, Brillas E (2009) Decontamination of wastewaters containing synthetic organic dyes by electrochemical methods: a general review. Appl Catal B 87(3-4):105-145
Modirshahla N, Behnajady MA, Mohammadi-Aghdam S (2008) Investigation of the effect of different electrodes and their connections on the removal efficiency of 4-nitrophenol from aqueous solution by electrocoagulation. J Hazard Mater 154(1-3):778-786

Mollah MYA, Schennach R, Parga JR, Cocke DL (2001) Electrocoagulation (EC): science and applications. J Hazard Mater 84(1): $29-41$

Mook WT, Aroua MK, Chakrabarti MH, Low CTJ, Aravind PV, Brandon NP (2013) The application of nano-crystalline $\mathrm{PbO} 2$ as an anode for the simultaneous bio-electrochemical denitrification and organic matter removal in an up-flow undivided reactor. Electrochim Acta 94:327-335

Ozyonar F, Karagozoglu B (2012) Systematic assessment of electrocoagulation for the treatment of marble processing wastewater. Int J Environ Sci Technol 9(4):637-646

Reyter D, Bélanger D, Roué L (2008) Study of the electroreduction of nitrate on copper in alkaline solution. Electrochim Acta 53(20): 5977-5984

Samatya S, Kabay N, Yüksel Ü, Arda M, Yüksel M (2006) Removal of nitrate from aqueous solution by nitrate selective ion exchange resins. React Funct Polym 66(11):1206-1214

Shrimali M, Singh KP (2001) New methods of nitrate removal from water. Environ Pollut 112(3):351-359

Sridhar R, Sivakumar V, Prakash Maran J, Thirugnanasambandham K (2013) Influence of operating parameters on treatment of egg processing effluent by electrocoagulation process. Int J Environ Sci Technol. doi:10.1007/s13762-013-0301-5

Tada K, Kawaguchi T, Shimazu K (2004) High electrocatalytic performance of $\mathrm{Pd} / \mathrm{Sn} / \mathrm{Au}$ electrodes for nitrate reduction. J Electroanal Chem 572(1):93-99

Thakur C, Srivastava VC, Mall ID (2009) Electrochemical treatment of a distillery wastewater: parametric and residue disposal study. Chem Eng J 148(2-3):496-505

Vasudevan S, Epron F, Lakshmi J, Ravichandran S, Mohan S, Sozhan G (2010) Removal of NO3- from drinking water by electrocoagulation: an alternate approach. Clean Soil Air Water 38(3): 225-229

Wang XM, Wang JL (2013) Nitrate removal from groundwater using solid-phase denitrification process without inoculating with external microorganisms. Int $\mathrm{J}$ Environ Sci Technol 10(5):955-960

WHO (2011) Nitrate and nitrite in drinking-water. World Health Organization, Genova

Xu X, Gao B, Yue Q, Li Q, Wang Y (2013) Nitrate adsorption by multiple biomaterial based resins: application of pilot-scale and lab-scale products. Chem Eng J 234:397-405

Yavuz Y, Öcal E, Koparal AS, Öğ̈̈tveren ÜB (2011) Treatment of dairy industry wastewater by $\mathrm{EC}$ and $\mathrm{EF}$ processes using hybrid Fe_Al plate electrodes. J Chem Technol Biotechnol 86(7): 964-969

Zhang S, Zhang J, Wang W, Li F, Cheng X (2013) Removal of phosphate from landscape water using an electrocoagulation process powered directly by photovoltaic solar modules. Sol Energy Mater Sol Cells 117:73-80 